\title{
TEACHING READING THROUGH THREE STAY ONE STRAY TOWARDS AT MA DARUSOLLIHIN NW KALIJAGA
}

\author{
Muhammad Muhlisin', Aprianoto ${ }^{2}$ \\ muhlisinzeko@gmail.com
}

\begin{abstract}
This investigation deal with quasi experimental in the form non-randomize control group design or non-equivalent by purposing at finding out teaching reading through three stay one stray. The investigation used total sampling technique in determining the sample of the research. The data was taken by using test in the form of multiples choice and it analyzed by using descriptive statistic and inferential analysis. Based on the data analysis was gotten that the result of analysis shown that t-test was higher than t-table. It can be inferred that alternative hypothesis accepted and null hypothesis rejected. Therefore, it concluded that there was significant effect teaching reading through three stay one stray.
\end{abstract}

Key words: Reading and Three Stay One Stray

\section{INTRODUCTION}

Background of the Study

Reading is one of the basic language skills. It is one of the important elements in language skills. Through reading can bridge someone to know something new or important knowledge and reading activity is also a mean to connect the reader and the writer's idea. People can read anything that they like and it is one of joyful activity. In addition, people can read anywhere as long as they felt comfortable. However, reading is not the isolated process. Reading helps the students become better writers. Through reading, students have incidental contact with the rule of grammar. Students develop a sense for the structure of the language in grammar and increase their vocabulary, (Johnson, 2008:7).

In reading activities, there is a critical thinking that also needs to be possessed by each student to think more critically in solving problems and understanding the reading material. Critical thinking in reading trains students to respond and identify points from the text. So, it can make students motivated to explain their arguments.

During pre observation doing at the sechool the researcher found out four problems in relation to the students' in reading at second grade students of MA Darusollihin NW
Kalijaga. The problems related on determining the idea of the sentences, finding the supporting and the students didn't understand to make conclusion when they reading the text.

Related on the problems faced by the students at the school. the researcher try to find solution of the problems by taking the title "teaching reading through three stay one stray towards at MA Darusollihin NW Kalijaga"

\section{Statement of the Problem}

Based on the background of the study above, the researcher formulated the statement of the problem as follow: Is there any effect of three stay one stray towards students' critical thinking in reading at MA Darusollihin NW Kalijaga?

\section{Significance of the Study}

There are two significances of this study, they are theoretically and practically. Theoretical can be used as the references in teaching learning process and practical can be used by the reaching in teaching reading.

\section{Definition of the Key Terms}

1. Reading

Reading is a skill that should be mastered by students in learning English. Reading not only read what is written but also understands the content of reading 
itself, so the reader can get the knowledge and information from the text.

2. Three Stay One Stray

Three stay one stray is a technique that plays in a group, where the students can exchange ideas and build social skill such as asking or probing question. It also offers students the opportunity to learn by teaching.

\section{REVIEW OF RELATED LITERATURE Definition of Reading}

According to Johnson (2008:4)

reading is a constantly developing skill. Like any skill, we get better at reading by practicing. And conversely, if we do not practice, we will not get better and our skills may deteriorate. From age three to one hundred and three, reading practice is what helps us become better readers.

Linse (2005: 69) argued that reading is making sense of printed word. However, teaching reading comprehension is not an easy job for the teacher. The teachers need to improve their teaching method or strategy in order to help the students to get the point in reading text. In order to know the meaning of printed word in reading, the readers need to read comprehensively.

\section{Indicators of Reading}

According to Chesla (2002:24) there are nine indicators of reading, those will be explained as follow:
a. Main Idea
b. Vocabulary
c. Specific fact or detail
d. Expectation
e. Location of Information
f. Reference
g. Paraphrased Sentence
h. Sentence Insertion

\section{Types of Reading}

According to Brown (1989), types of reading are intensive reading and extensive reading. These differences are determined by the purpose of reading. a. Intensive reading

1. In intensive reading "the main focus is on grammatical forms, discourse markers, and other surface structure details for the purpose of understanding literal meaning, implications, rhetorical $\mathrm{r}^{1}{ }^{\mathbf{}}{ }^{-}$ionships, and the like".

2. It is classroom paced.

3. Texts are short (not more than 500 words) and leveled.

b. Extensive reading

The characteristics of extensive reading:

1. It is done for enjoyment.

2. It is individual-paced.

3. A variety of texts and materials are used.

4. Students read for main ideas, not for details.

\section{Three Stay One Stray}

Definition of Three Stay One Stray

Three stay one stray is the kind of structure in cooperative learning. Cooperative learning is a success teaching strategy in which small teams, each with students of different levels of ability, use a variety of learning activities to improve their understanding of a subject.

(http://edtech.kennesaw.edu/intech/cooperative learning.htm)

Three stay one stray is a technique for having groups report out results of their discussion when there is no time to hear from each group. Groups are given a problem to solve and are told to make sure that everyone in the group understands the solution that the group has come up with. Then one member of each group is selected to "stray" by going to the next group. At the new group, the designated student is welcomed as a visitor then briefs the three who have remained on the findings of the student's original group. Each group, in other words, learns the findings of another group and has its finding reported to another group. It is important that student who will be reporting is not told beforehand until the last minutes, so that each student must be 
ready to represent the groups. Millis describes the benefits of this process this way:

Three Stay one Stray offers a low-threat forum where students can exchange ideas and build social skills such as asking probing questions. It also offers students the opportunity to learn by teaching. Placing the report-out responsibility on the students reinforces the valuable conception that knowledge resides within the learning community, not just with the "authority-figure" instructor (Millis, 2011).

\section{Procedure of Three Stay One Stray}

Here some steps or procedures of holding Three Stay One Stray are as the following:

a. Students get worksheet and discuss it together in their own group.

b. In a given time, teacher asks one student from every group goes to the other group to see or take the information (the student who goes is determined by the teacher).

c. Three other students stay in group to give the result of their discussion to quest.

d. The student who stray gets back to his/her own group and tell the member what information she/he has gotten.

e. Every group to check the finding and rehash their group result.

f. During teaching and learning process, teacher's and students' activities would be observed. The researcher will use observation sheets and field notes in noting all things happened while doing the research.

g. In this reflection phase, the researcher specified and analyzing what she has done in teaching activity in the classroom.

\section{Advantage and Disadvantage of Three Stay One Stray}

Lie (2002) point out the advantage and disadvantage of Three Stay One Stray strategy will explain as follow:

a. The advantage of Three Stay One Stray Strategy:
1) Giving an opportunity to the students to decide their own concept by solving the problem which is given to them.

2) Giving an opportunity to the students to build their creativity and to communicate with their friend in grouping.

3) Forming the habit of the students to open minded with their friends.

4) Increasing the students' motivation in learning.

5) Helping teacher to reach learning goal, because the cooperative learning method is easy to be applied.

\section{The disadvantage of Three Stay One Stray Strategy:}

1) TSOS needs more time for discussion.

2) Students who seldom work in group will feel difficult to cooperate.

3) Generally, fluent students in discussing usually dominate the discussion.

\section{RESEARCH METHOD \\ Research Design}

The method used in this research was quasi-experimental method with the Nonequivalent Control Group Design. According to Singh (2007:67-68), quasi experimental studies have some attributes of experimental research design as they involve some controls over extraneous variables when full experimental control is lacking. Quasi-experiment is a type of quantitative research design conducted to explain relationship and/or clarify why certain events happen. It analyzed the difference in the treatment and the control group to look for causality in situations when complete control was not possible. These designs were developed to examine causality in situations where it was not practical or possible to have complete control over the subjects.

\section{Population of the Study}

According to Sugiyono, $(2015: 117)$ the population is the generalization with consist of object and subject that have certain quantity and characteristics divided by the researcher to 
learn and draw conclusion. Related on the design used, the researcher used total sampling technique in determining the sample.

\section{Technique of Data Analysis}

Procedure of data analysis used in this research include two steps; the first is descriptive statistics and inferential analysis. Descriptive analysis used to describe or showing the research object from the sample that include mean, median, mode and standard deviation. Inferential Statistics used to decide whether the independent variable is having the effect we supposed, or whether, perhaps, there is no real difference between the performances of the two groups. This is the function of inferential statistics.

\section{RESEARCH FINDING AND DISCUSSION}

Descriptive analysis of the data performed to determine the range of the data, the mean, median, mode, and standard deviation. These data were taken from the post test result of students in each group. A statistical calculation and test performed through SPSS 2.6. Software as well as analysis and interpretation.

The data of reading pre-test score in experimental class were obtained through instrument of objective multiple-choice test that consisted of 25 questions, each correct answer scored 4 and incorrect answer scored 0 , the maximum score was 100 and the minimum was 0 . Respondents treated by TSOS strategy were 26 students. The empiric score stated that the highest score was 68, the lowest score was 28 . Furthermore, mean score was 41.3846, median was 42.0000 , mode was 44.00 , and standard of deviation was 10.60972. The complete result gained from calculation can be seen below.

The mean score 41.3846 indicated that the average score for the students was good. The standard deviation10.60972 indicated that the answers given by the students using TSOS strategy were relatively the same.

Graphic 4.3 Histogram Reading PreTest Control

Jurnal Ilmu Sosial dan Pendidikan

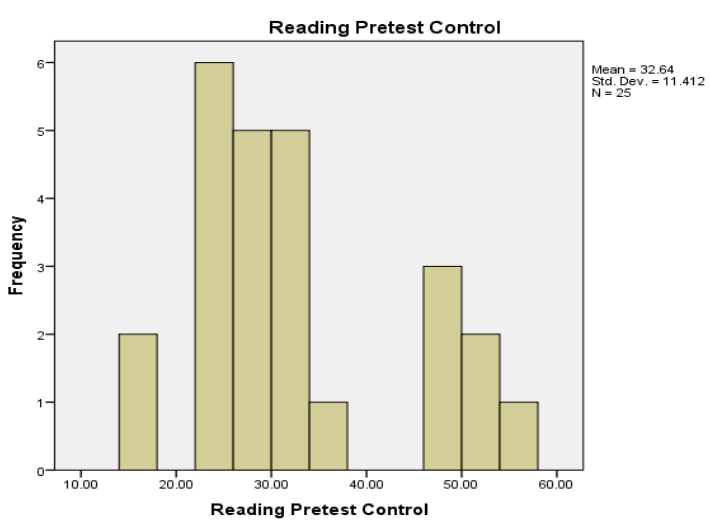

The data of reading post-test score of control class were ained through instrument of objective ......tiple-choice test that consisted of 25 questions, each correct answer scored 4 and incorrect answer scored 0 , the maximum score was 100 and the minimum was 0 . Respondents treated by TSTS strategy were 25 students. The empiric score stated that the highest score was 80 , the lowest score was 36 . Furthermore, mean score was52.9600, median was 48.0000 , mode was 40.00 , and standard of deviation was 12.92440. The complete result gained from calculation can be seen below.

The mean score 52.9600 indicated that the average score for the students was relative not good. The standard deviation 12.92440 indicated that the answers given by students using TSTS strategy were relatively not same. To make it clear, it can be seen in the display of histogram and polygon presented below:

Graphic 4.4 Histogram Reading PostTest Control

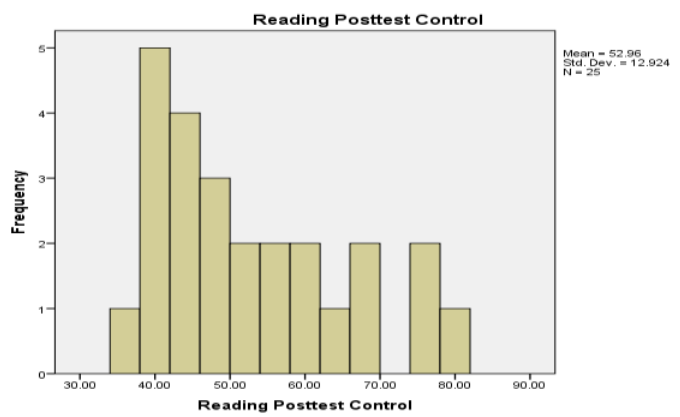

\section{Testing Hypothesis}

Testing hypothesis was to answer the questions of alternative hypothesis was 
accepted or null hypothesis was rejected. The hypothesis was tested by using t-test to get the answer of question. To find out the result of t-test, the researcher calculated the data of experimental and control class. In this research, the sample of data was 26 students in experimental class and 25 students in control class. The total samples of both of groups were 51 students.

Table 4.6

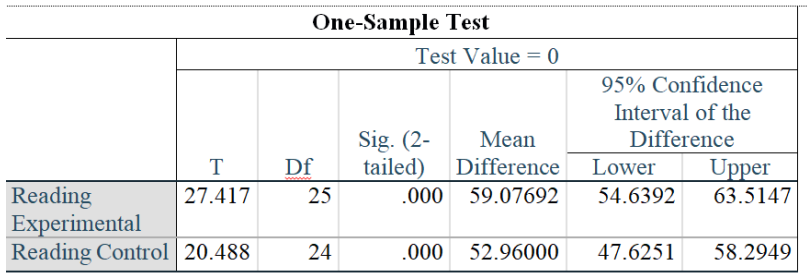

\section{Discussion}

When the researcher used Three Stay One Stray strategy in teaching reading, the students were more active because in Three Stay One Stray strategy they can discussed and played role with their friends during teaching learning process that made students easier to comprehend the text. Collaborative Strategic Reading strategy was a reading strategy useful for dividing up texts and checking understanding before you move on. It meant that the students should understand a section of the text before they move into the next section of the text. This strategy also offers a low-threat forum where students can exchange ideas and build social skills such as asking probing questions.

By applying Three Stay One Stray (TSOS) strategy, students can be directed to think through written text to improve their reading skill. In addition, the OSTS strategy can encouraged learners to think effectively to gained a good understanding. In this strategy, the prediction was a strategic step to improved and gained a better understanding of reading. Therefore, students were able to catch the main idea of the texts being read. In the TSOS strategy, students had wide chance to delivered their idea or understanding on written text. This learning process made them enjoy their reading activities and ease them to interpret and respond to the content of reading texts.

Based on the data obtained, the result showed that the score of students' reading comprehension taught by TSOS strategy (experimental class) was higher than OSTS strategy (control class).

\section{CONCLUSION}

Based on the data analysis and discussion in previous chapter, it can be concluded that three stay one stray is appropriate in teaching critical thinking in reading. Three Stay One Stray (TSOS) strategy helps the students to increase their critical thinking in learning reading. Based on t-test computation, the researcher found out three stay one stray gave positive effect towards students' critical thinking in reading at MA AlMadani Kuripan, because the result showed that t-test (27.417) was higher than t-table (2.0075). it means that $27.417 \geq 2.0075$, it can be concluded that the alternative hypothesis (Ha) was accepted, while null hypothesis (Ho) was rejected.

\section{BIBLIOGRAPHY}

A Committee of Specialists from Education Ministry. 2014-2015. Guided Reading Manual

Johnson P. Andrew. 2008. Teaching Reading and Writing. United State of America:

Published by Rowman \& Littlefield Education

Kagan Spencer. 2009. Kagan Cooperative Learning

Kothari C. R. 2004. Research Methodology. New Delhi: Published by New Age International (P)

L. Elizabeth Chesla. 2000. Learning Express, LLC. United State: Published by Learning Express, LLC, New York.

Miller Steve. 1984. Experimental Design and Statistics.

Singh Kultar. 2007. Quantitative Social Research Method. New Delhi: Published 
Jurnal Ilmu Sosial dan Pendidikan

http://ejournal.mandalanursa.org/index.php/JISIP/index

Terakreditasi Peringkat 5 (No. SK: 85/M/KPT/2020)

Vol. 4. No. 3 Juli 2020

p-ISSN: 2598-9944 e- ISSN: 2656-6753

by Sage Publications India Pvt

Sugiyono. 2007. Statistik Untuk Penelitian.

Bandung: Published by CV Alfabeta 